\title{
Conception of the Maritime Transport Safety in the Baltic Sea in 2009 to 2015
}

Jacek Caban $^{1 *}$, Eva Brumercikova ${ }^{2}$, Bibiana Bukova ${ }^{2}$, Frantisek Brumercik ${ }^{3}$, Ján Vrábel ${ }^{2}$, Branislav Šarkan $^{2}$ and Piotr Ignaciuk ${ }^{4}$

${ }^{1}$ University of Life Science in Lublin, Faculty of Production Engineering, 20-612 Lublin, Poland; Email: jacek.caban@up.lublin.pl

${ }^{2}$ University of Zilina, Faculty of Operation and Economics of Transport and Communications, Univerzitná 1, 01026 Žilina, Slovakia; Email: eva.brumercikova@fpedas.uniza.sk, bibiana.bukova@fpedas.uniza.sk,vrabel@fpedas.uniza.sk,Sarkan@fpedas.uniza.sk

${ }^{3}$ University of Zilina, Faculty of Mechanical Engineering, Univerzitná 1, 01026 Žilina, Slovakia; Email: frantisek.brumercik@fstroj.uniza.sk

${ }^{4}$ Lublin University of Technology, Mechanical Engineering Faculty, 20-618 Lublin, Poland; Email: p.ignaciuk@pollub.pl

\section{*Corresponding Author: Jacek Caban}

Abstract: The maritime transport is particularly exposed to danger due to the environment of its operations. These are the threat dependent and independent of human e.g. environmental, safety health and life of humans or belongings. In spite of attempts to limit the risk of danger, it is impossible to completely eliminate it. The article presents some aspects of the state of transportation safety in the Baltic Sea from Statistical Yearbook of Maritime Economy and Helcom as well as attempt the undertaken to analyses the security state of this sea area in 2009 to 2015.

Keywords: Maritime transport, maritime safety, maritime accidents, Baltic Sea

\section{Introduction}

Shipping is also a highly regulated domain, and regulations have been reinforced in the last two decades [1]. The main principles underlying shipping regulations are harmonized by national rules based on international conventions and resolutions given by the International Maritime Organization (IMO) [2]. At the level of the European Union (EU), the European Commission (EC) introduces the regulations, determined at the IMO, into binding laws, with the support of the European Maritime Safety Agency (EMSA) [3]. Further, the rules are adapted to regional conditions by the Baltic Marine Environment Protection Commission (Helsinki Commission, HELCOM), an intergovernmental organization of nine Baltic coastal countries and the EU [4]. In the globally orientated maritime safety regime, the regional role of the HELCOM in the Baltic Sea is significant [5]. The aim of HELCOM is protected by the marine environment in the Baltic Sea from all sources of pollution. It collects data related to maritime traffic, accidents and oil transportation, gives 
recommendations related to maritime safety and pollution from ships, and coordinates multilateral responses in case of major maritime incidents [5].

Since the inception of maritime transport, there are also factors presenting all kinds of dangers in this transport sector. Therefore, we can assume that the dangers accompanying maritime transport are continuous in time, impossible to be eliminated entirely, and also amenable to changes in parallel with the development of civilization. The International Convention for the Safety of Life at Sea (SOLAS) of the IMO recommends Vessel Traffic Services (VTS) for areas in which the volume of traffic or the risk of accident is high [6].

Maritime safety is referred to as safety of life, health and property from operating and environmental hazards, and the safety of the marine environment against pollution which is a byproducts of human activities at sea. The maritime economy is particularly exposed to danger due to the environment of its operations. These risks result from deliberate actions, as well as random event (weather conditions, the mechanical elements state, etc.). At the same time, it is a collection of punk logistics necessary for the functioning of global economy. Maritime transportation plays a significant role in the integrated transportation system, especially in international trade system [7]. Nowadays it is difficult to imagine international trade without the participation of the maritime transport, which accounts for about $90 \%$ of the freight. Around $90 \%$ of world trading is carried out by the shipping industry [1]. Safety is a crucial factor due to the fact that various accidents like ship collisions and groundings often result in great economic loss, fatalities and the environmental contamination [7].

The article presents some aspects of transport security in the Baltic Sea and an attempt was made to analyse the security situation of this sea area. One objective of the study is to show the causes of maritime accidents in the Baltic Sea Area.

\section{The Baltic Sea Transport Safety}

Dynamic development of maritime transport in the Baltic Sea region is stimulated by a variety of factors [8]. These factors - both external and internal, that is, inter-Baltic and market, and nonmarket, transport and non-transport - affect with different strength the size and structure of transport by sea [8]. The Baltic Sea is relatively small and closed, and thus particularly sensitive to threats [9], measuring mean depth of 50 meters. While maritime transport is of vital economic importance to the Baltic Sea Area, challenging winter navigation conditions pose additional hazards to ships operating in these waters [10]. The increase in migration of people and the circulation of goods by sea has caused an increase in the volume of traffic on sea routes, while technological progress has made it possible to build vessels with a large carrying capacity. According to IMO [11], the Baltic 
Sea Area has some of the most hazardous maritime traffic in the world [12]. This has contributed significantly to the increase in number of accidents on the sea routes, and also created a real threat to the marine environment [13].

Several maritime accidents tragically demonstrate that an accurate assessment of the situation as well as timely and right decisions both aboard the emergency vessel and by the Search and Rescue (SAR) authorities are of paramount importance when attempting to save the people aboard and for ensuring the safety of the vessel itself [14]. Accidents where inadequate information and communication about the vessel's condition have been identified as factors needing improvement are for instance the flooding and foundering of the Abigail $\mathrm{H}$ [15], the grounding and capsizing of the Costa Concordia [16] and the grounding and flooding of the Commodore Clipper [17] or MS Jan Heweliusz.

In the early hours of January 14th 1993, MS 'Jan Heweliusz' capsized close to Cape Arcona on the coast of Rügen in the Baltic Sea while sailing toward Ystad with 64 passengers and crew. A correct accident investigation has never been done as per international law and the IMO resolutions [18], and during the summer 2002 the process to make a review of new findings has started - this time in the European Court of Human Rights [19]. The ship was on a northerly course in the South Baltic Sea and was subject to strong westerly wind, which in the end was up to $50 \mathrm{~m} / \mathrm{s}$, much more than foreseen by any weather report [19]. When the wind just continued to increase, the Captain took the fatal decision trying to head into wind and waves [19]. He didn't manage to keep the vessel into the wind but turned and got the wind on the other side [19]. The ballast, which was on the left side together with the wind pressure, caused the angle of listing to pass GZ-max when the vessel capsized [19]. MS 'Jan Heweliusz' sank after a while and was resting with the keel up. There is still a lot of uncertainty and doubt around the sinking of the ship 'Jan Hevelius'. So the clarification of this matter is becoming increasingly indispensable.

One area where improvements are considered necessary by especially SAR operators is the communication and information exchange between vessel crew, SAR operators and other relevant parties in maritime distress situations [14]. The importance of shared situational awareness and the quality of information in emergency situations is also stressed by Luokkala and Virrantaus [20] and Seppänen and Virrantaus [21], who highlight the importance of narratives in information sharing.

Every ship, both passenger and cargo is a potential threat to the environment, as fuel and cargo of all kinds can get out of it into the sea. The presence of chemicals in the marine environment contributes to the imbalance of the sea's health and life, as well as reduces the aesthetic of the marine environment [9]. Accidents that happen during transport on shipping routes are difficult to predict. Therefore, sea transport is characterized by a high potential of danger [22]. In the face of 
these problems there is the necessity of regulating administrative legislation as well as technical and quality standards, the aim of which is to protect the life and the marine environment.

\subsection{Types of Maritime Accidents}

Marine casualty is referred to as an unintended event resulting in death, injury, loss of the ship or its damage, or damage caused to the marine environment. There are the following types of maritime accidents [9]:

- collisions,

- contact with an obstacle,

- sinking,

- fire,

- damage to the hull,

- damage to the engine room,

- war losses,

- stranding,

- oil spill,

- accidents with people,

- other accidents.

\section{Data Analysis}

Until recently, there was no necessity, and the ability to assess the level of threats at sea. Only since the 50s of last century, when significantly increased transport of dangerous goods, particularly oil and gas, extremely increased threat to the marine environment [23]. The best measure of safety of navigation on a particular sea area is data about accident rates of ships [24]. On the basis of the HELCOM [25] report in the year $201244 \%$ of the accidents took place in ports, $35 \%$ in the open sea, and $14 \%$ occurred during the approach to port and $7 \%$ of accidents were unidentified. In the years 2009 to 2015 in the Baltic Sea Area there were near 439 accidents.

Figure 1 shows the number of accidents in the years 2009 to 2015. 


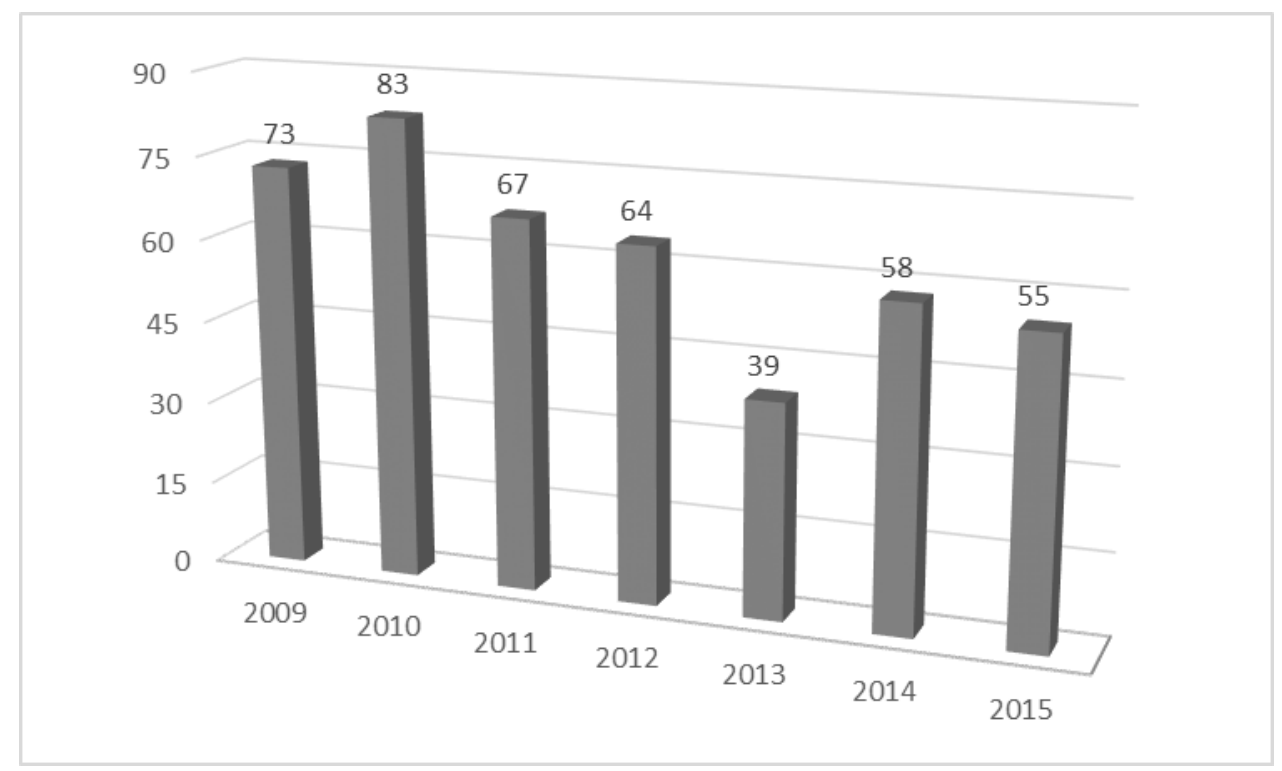

Fig. 1 Total number of maritime accidents occurring in the years 2009 to 2015 .

Source: authors, based on [26-28]

Due to the civilization and structural development of economy, factors threatening the security of maritime transport are also changing. Figure 2 shows the causes of accidents in the maritime transport sector in the years 2009 to 2015.

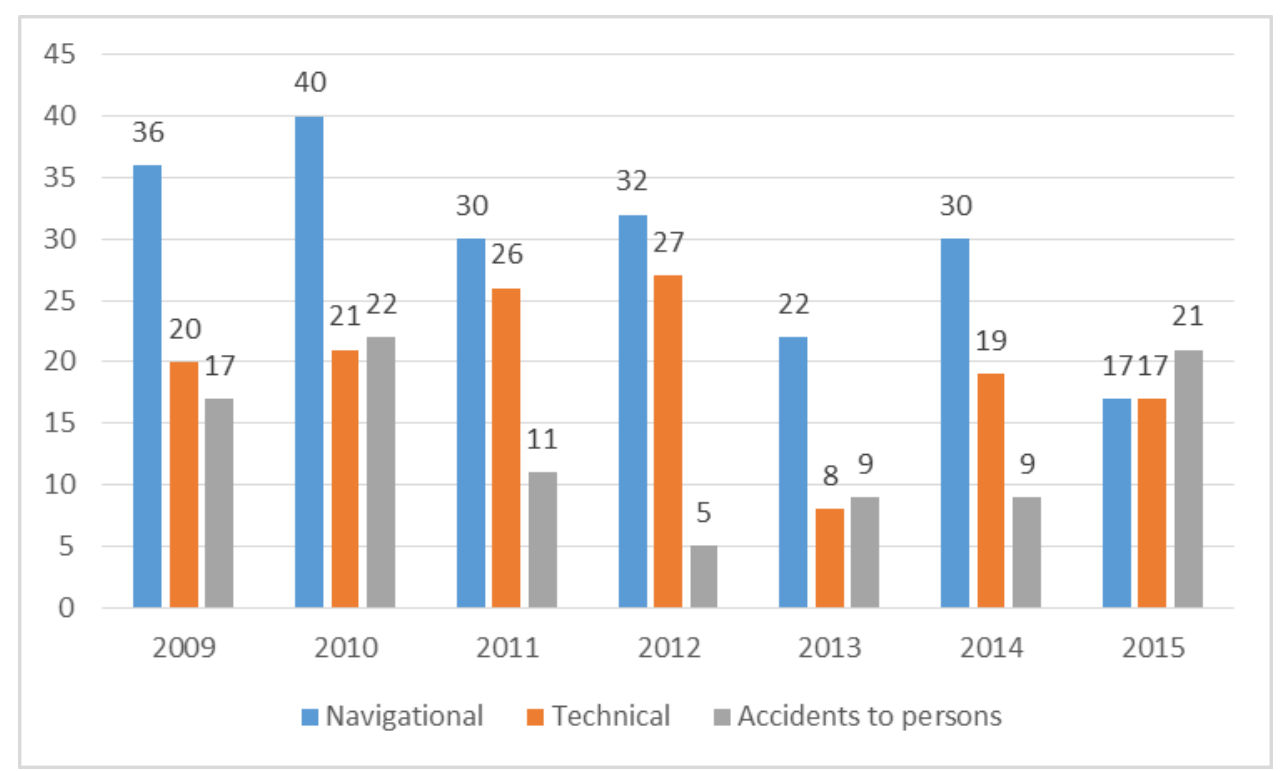

Fig. 2 General classification of types of maritime accidents occurring in the years 2009 to 2015 . Source: authors, based on [26-28]

The largest group of accidents are accidents resulted by navigation errors. The decisive factor in the advantage of this type of accidents are caused by human factors (errors in reading the location, bad training of the crew, etc.), and possible malfunction of the navigation instrumentation. A false sense of security "guarded" by electronics (radars equipped with ARPA, Automatic Identification System AIS, electronic maps, etc.), results in a fairly rapid growth of maritime accidents [24]. 
Lowering the vigilance of the navigator takes place on the open waters. Since 2009, the number of accidents decreased, except for technical reasons, that may be caused by cutting production costs and lowering standards of components implementation.

Figure 3 shows in detail the number of accidents which occurred for reasons of navigation.

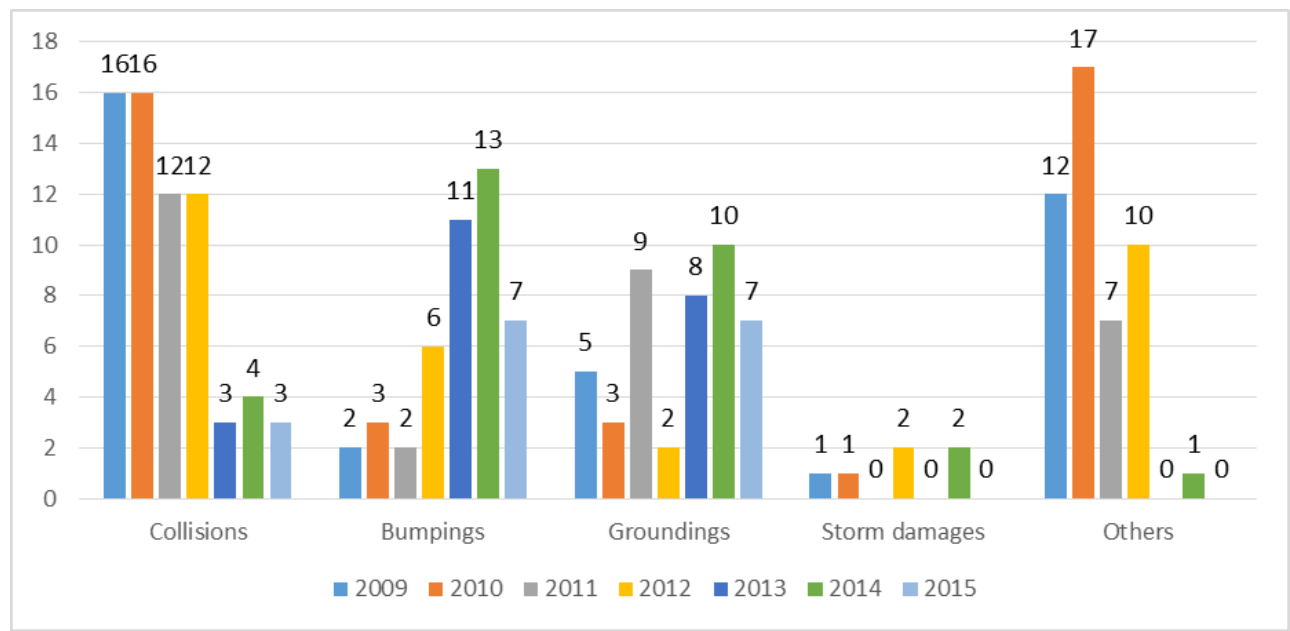

Fig. 3 Detailed classification of accidents due to navigation causes in the years 2009 to 2015 .

Source: authors, based on [26-28]

Navigation accidents can be divided into several main groups, the largest ones, consisting of collisions, bumpings, groundings and storm damages. The largest number of collisions took place in 2009 and 2010, bumpings in 2013 and 2014 as well as grounding in the year 2014 and 2011. The largest number of others accidents was in 2010. As you can see in the graph (Fig. 3), the least navigational incidents occurred in 2015.

Figure 4 shows the number of accidents which occurred due to technical reasons.

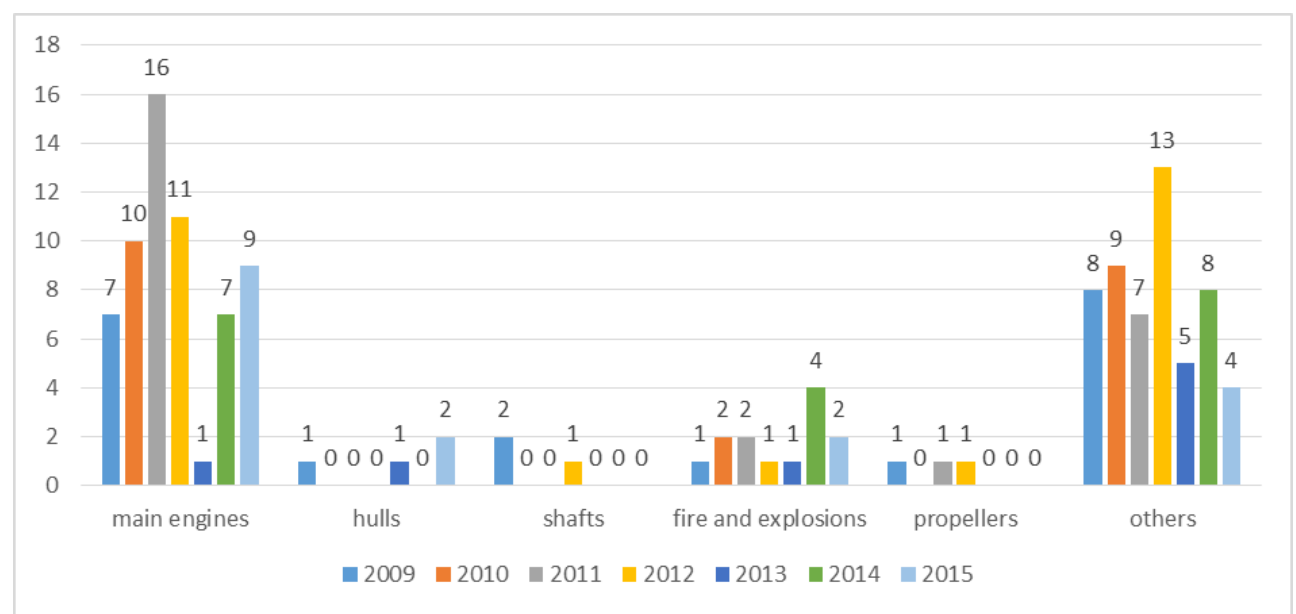

Fig. 4 Number of accidents due to technical reasons in the years 2009 to 2015 .

Source: authors, based on [26-28]

The most common causes of accidents due to technical reasons are main engine failures. The largest number of accidents reported in the year 2011, this number dropped significantly in the year 
2014. Accidents due to unsealing hulls, damages to drive shafts and propellers, and fires are relatively rare compared to the damage to engines which are clearly the predominant factor.

Figure 5 shows the detailed classification of maritime accidents caused by human factor.

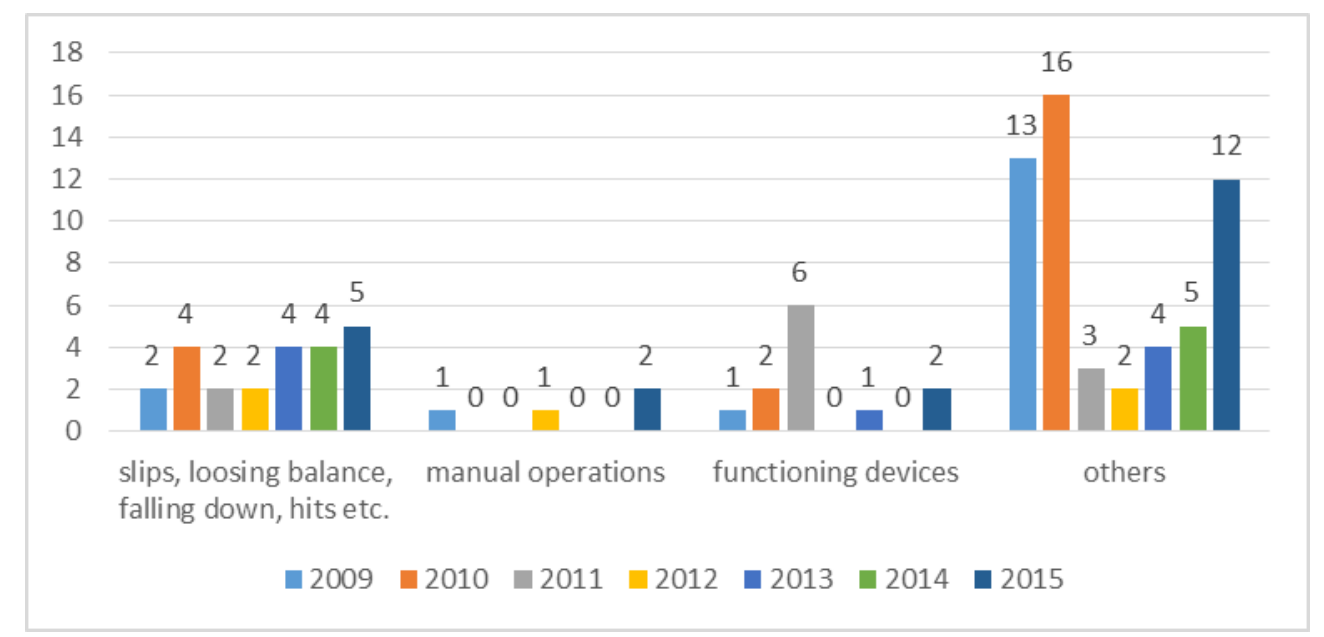

Fig. 5 Detailed classification of accidents caused by human factor in the years 2009 to 2015 . Source: authors, based on [26-28]

The number of marine accidents caused by human factor significantly decreased in the year 2010 - 22 accidents and 2015 - 21 accidents. Random accidents such as slip or loosing balance are at a similar level in view of the difficulty of eliminating these types of events that occur in an uncontrolled way. Most of the accidents caused by devices in services were reported in the year 2011, and in 2012 they were eliminated, but in 2013 was 1 and 2015 - 2, of this type of accidents. The largest number of other reported accidents was in 2010. This type of accident is the highest in all the years analyzed.

\section{Actions in Favour of Maritime Transport Safety}

To prevent any kind of threats to maritime transport governments and international organizations significantly expanded their activities. Of great importance is the fact of adequate preparation of the crews of ships. Almost every company has special instructions in situations threatening the life or health of the crew and/or passengers [29]. This also applies to defend against attacks on the unit (piracy). Although at present the phenomenon of armed assaults on ships is limited largely to selected and well known maritime routes, anytime it can occur on any point on the globe, including areas recognised for being "civilized". Similarly, in the case of disasters caused unintentionally, or such, which could have been prevented, it can happen almost anywhere [30]. For this purpose specialized systems have been developed, having the task of crisis management at sea:

- Safety \& Security Information Exchange System (MarSSIES), which is aimed to distribute information concerning maritime safety between the selected entities with the appropriate terminals, 
- Ship Traffic Monitoring and Information System, created in order to facilitate maritime traffic, especially those that carry dangerous goods.

Maritime transport, in order to ensure its optimum conditions was subject to international legal acts. The most important of these include: SOLAS and MARPOL Convention [31]. These relate to maritime safety, ship construction, carrying out listening in control during the cruise, as well as units equipped with safety equipment and prevention of marine pollution equipment. Both the national and international regulations impose specific obligations on each transport participant (the manufacturer, consignor, shipper, carrier and consignee) [30].

Coastal states are required to organize and equip the sea rescue services. The reactive security management is also used for improving the level of safety at sea. It involves, inter alia, drawing conclusions from the effects arising after collisions or accidents, and on their basis safety systems are improved and additional security and protection is introduced [13]. For this purpose, dangerous situations are analyses and then are conclusions drawn, which should contribute to changes in the legislative, security system to raise the level of security and thus reduce the level of risk of danger at sea.

Maritime Search and Rescue services (SAR) People in distress or at sea, include such activities as: helping ships and ships in difficulty, preventing accidents, searching and rescue, medical consultation and patient transport [14]. Maritime SAR has a legal basis in multi-lateral conventions and documents, in particular the International Convention for the Search of the Sea and Rescue (with later amendments) [32], the International Convention for the Safety of Life at Sea (SOLAS, as amended) [33] and the International Aeronautics and Maritime Search and Rescue Manual (IAMSAR, as amended) [34]. Additionally, national authorities implement bi-lateral agreements and national acts and decrees.

In 2007, the HELCOM launched the Baltic Sea Action Plan (BSAP) to restore the good ecological status of the Baltic marine environment, and to provide a real basis for the HELCOM's work. In addition to the aims related to reducing eutrophication and hazardous substances, and improving the status of biodiversity in the Baltic Sea, the program aims at enhancing the environmental friendliness of maritime activities in the Baltic Sea [35 and 36]. The BSAP is supported by the EU Strategy for the Baltic Sea Region (EUSBSR) [37], which promotes cooperation between stakeholders and sectors, in order to improve the environmental condition of the sea. Currently, the maritime industry is starting to implement proactive approaches and has tried to avoid reoccurrences by implementing an appropriate safety culture [38]. A positive safety culture with commitment from all levels in the company can achieve the envisaged and required safety levels in the maritime industry [38]. 


\section{Conclusion}

In conclusion, it should be noted that there are a lot of components threatening the safety of sea routes, as well as degrading the environment. By pursuing comprehensive efforts to raise the level of safety in maritime transport it is possible, however, to reduce the risk of these threats. These include a.o. all kinds of alarm systems, rescue, tailored legislative conditions for the preparation of ship-owners and crews of ships for defensive action. Particularly important are safety issues during cargo handling in ports and transport terminals [39]. The increased number of sailings on maritime routes endangers the environment and causes all sorts of accidents or collisions.

In the analyzed period (2009-2015), in the Baltic Sea Area occurred nearly 439 accidents. On the basis of the analysis, it has been shown that the largest group of accidents is represented by accidents caused by navigational errors, followed by technical and the last is accidents to people. It has been shown, that the number of accidents related to people significantly decreased in the year 2012. The lowest number of technical accidents took place in 2013 (22 accidents). Moreover, it has been demonstrated that most of the causes of accidents caused by equipment operation occurred in 2011, which in 2012 they were eliminated. The most common cause of accidents due to technical failures was the main engines. In the category of navigational accidents it has been shown that the greatest number of collisions took place in 2009 and 2010, bumpings in 2013 and 2014 and stranding in 2011 and 2014.

\section{Acknowledgments}

This work was carried out in partnership between University of Life Sciences in Lublin and University of Zilina, as well as Lublin University of Technology and supported by the Slovak Scientific Grant Agency of the Slovak Republic under the project No. VEGA 1/0095/16.

\section{References}

[1] Chauvin, C., Lardjane, S., Morel, G., Clostermann, J.P. \& Langard, B. (2013). Human and organisational factors in maritime accidents: Analysis of collisions at sea using the HFACS. Accident Analysis and Prevention, 59, 26-37.

[2] Kristiansen, S. (2008). Marine safety - Background, In: A. Molland (Ed.), The Maritime Engineering Reference Book, Butterworth Heinemann, (Chapter 11), 786-875.

[3] European Maritime Safety Agency (EMSA). (2009). Quality Shipping, Safer Seas, Cleaner Oceans. Lisbon 2009, from http://www.roodbovengroen.com/website/ managedMedia/mediaItem/159.pdf. 
[4] Hassler, B. (2010). Global regimes, regional adaptation; environmental safety in Baltic Sea oil transportation. Maritime Policy Management, 37, 489-503.

[5] Haapasaari, P., Helle, I., Lehikoinen, A., Lappalainen, J. \& Kuikka, S. (2015). A proactive approach for maritime safety policy making for the Gulf of Finland: Seeking best practices. Marine Policy, 60, 107-118.

[6] International Maritime Organization (IMO). (2015). Vessel Traffic Services, from http://www.imo.org/OurWork/Safety/Navigation/Pages/VesselTrafficServices.aspx.

[7] Zhang, J., Yan, X., Zhang, D., Haugen S. \& Yang, X. (2014). Safety management performance assessment for Maritime Safety Administration (MSA) by using generalized belief rule base methodology. Safety Science, 63, 157-167.

[8] Grzelakowski, A.S. (2010). Rozwój transportu morskiego w regionie Morza Bałtyckiego (in Polish). Zeszyty Naukowe Akademii Morskiej w Gdyni, 67, 73-88.

[9] Bogalecka, M. (2012). Bezpieczeństwo transportu morskiego w regionie Morza Bałtyckiego (in Polish). Journal of Management and Finance, 3(1), 574-584.

[10] Aps, R., Fetissov, M., Goerlandt, F., Helferich, J., Kopti, M. \& Kujala, P. (2015). Towards STAMP based dynamic safety management of eco-sociotechnical maritime transport system. In 3rd European STAMP Workshop, STAMP UE 2015. Procedia Engineering, 128, 64-73.

[11] IMO, Designation of the Baltic Sea area as a particularly sensitive sea area. (2015). Resolution MEPC, 136(53).

[12] Aps, R., Fetissov, M., Goerlandt, F., Kujala, P. \& Piel, A. (2017). Systems-Theoretic Process Analysis of maritime traffic safety management in the Gulf of Finland (Baltic Sea). In 4th European STAMP Workshop 2016. Procedia Engineering, 179, 2-12.

[13] Dyrcz, Cz. (2005). Terroryzm początku XX wieku jako zagrożenie bezpieczeństwa międzynarodowego i narodowego (in Polish), Gdynia: AMW.

[14] Nordström, J., Goerlandt, F., Sarsama, J., Leppänen, P., Nissilä, M., Ruponen, P., Lübcke, T. \& Sonninen, S. (2016). Vessel TRIAGE: A method for assessing and communicating the safety status of vessels in maritime distress situations. Safety Science, 85, 117-129.

[15] MAIB. (2009). Report on the Investigation into the Flooding and Foundering of the Grab Hopper Dredger Abigail H in the Port of Heysham 2 November 2008 (No. 15/2009). Marine Accident Investigation Branch, Southampton, UK. 
[16] MIT. (2013). Cruise Ship Costa Concordia Marine Casualty on January 13, 2012 - Report on the Safety Technical Investigation. Ministry of Infrastructures and Transports.

[17] MAIB. (2015). Report on the Investigation of the Grounding and Flooding of the ro-ro ferry Commodore Clipper in the Approaches to St Peter Port, Guernsey on 14 July 2014 (No. 18/2015). Marine Accident Investigation Branch, Southampton, UK.

[18] Björkman, A. (2007). Estonia re-visited. The Naval Architect, January, 6-7.

[19] Björkman, A. (1993). Sten Anderson ljuger om M/S 'Jan Heweliusz'. Sten Anderson of the Swedish Maritime Administration Lies about M/S 'Jan Heweliusz' sinking 14 January 1993, from http://heiwaco.tripod.com/stenanderson.htm.

[20] Luokkala, P. \& Virrantaus, K. (2014). Developing information systems to support situational awareness and interaction in time-pressuring crisis situations. Safety Science 63, 191-203.

[21] Seppänen, H. \& Virrantaus, K. (2015). Shared situational awareness and information quality in disaster management. Safety Science, 77, 112-122.

[22] Kopacz, Z., Morgaś, W. \& Urbański, J. (2007). Europejski System Monitoringu Ruchu Statków i Informacji (in Polish). Zeszyty Naukowe Akademii Marynarki Wojennej w Gdyni, 2(169), 41-58.

[23] Szubrycht, T. \& Rokiciński, K. (2006). Gospodarka morska w świetle wybranych zagrożeń współczesnego świata (in Polish), Gdynia: AMW.

[24] Marcjan, K. \& Gucma, L. (2014). Wykorzystanie analizy incydentów nawigacyjnych w celu oceny bezpieczeństwa nawigacyjnego na obszarach Morza Bałtyckiego o dużym zagęszczeniu ruchu statków (in Polish). Prace Naukowe Politechniki Warszawskiej. Transport, 102, 77-86.

[25] Annual report on shipping accidents in the Baltic Sea area during 2012. (2012). Baltic Marine Environment Protection Commission (HELCOM).

[26] Statistical Yearbook of Maritime Economy. (2015). Warsaw-Szczecin.

[27] Statistical Yearbook of Maritime Economy. (2014). Warsaw-Szczecin.

[28] Statistical Yearbook of Maritime Economy. (2016). Warsaw-Szczecin.

[29] Łusznikow, E.M. \& Ferlas, Z. (1998). Bezpieczeństwo Żeglugi (in Polish). Szczecin: Wyższa Szkoła Morska w Szczecinie.

[30] Wróbel, K. (2009). Zintegrowane systemy bezpieczeństwa morskiego (in Polish). Zeszyty Naukowe Akademii Morskiej w Gdyni, 63, 95-103. 
[31] Naus, K. (2008). Możliwości wykorzystania Systemu Wymiany Bezpieczeństwa Żeglugi w zarządzaniu kryzysowym (in Polish). Zeszyty Naukowe Akademii Marynarki Wojennej w Gdyni 4(175), 71-76.

[32] UN. (1979). International Convention on Maritime Search and Rescue.

[33] IMO. (1974). International Convention for the Safety of Life at Sea (SOLAS).

[34] ICAO, IMO. (2013). International Aeronautical and Maritime Search and Rescue (IAMSAR) Manual. Int. Civ. Aviat. Organ. Int. Marit. Organ. I-III.

[35] Helsinki Commission (HELCOM). (2007). HELCOM Baltic Sea Action Plan. HELCOM Ministerial Meeting, Krakow, Poland, 15 November 2007, from http://www.helcom.fi/Documents/Baltic\%20sea\%20action\%20plan/BSAP_Final.pdf.

[36] Backer, H., Leppänen, J., Brusendorff, A.C., Forsius, K., Stankiewicz, M., Mehtonen, J., Pyhäläa, M., Laamanen, M., Paulomäki, H., Vlasov, N. \& Haaranen, T. (2010). HELCOM Baltic Sea Action Plan, and regional programmer of measures for the marine environment based on the Ecosystem Approach. Marine Pollution Bulletin, 60(5), 642-649.

[37] Commission of the European Communities (CEC). (2009). Communication from the Commission to the European Parliament, the Council, the European Economic and Social Committee and the Committee of the Regions concerning the European Union Strategy for the Baltic Sea Region, COM (2009). 248 final; Brussels, 10.6.2009.

[38] Arslan, V., Kurt, R.E., Turan, O. \& De Wolff, L. (2016). Safety culture assessment and implementation framework to enhance maritime safety. In 6th Transport Research Arena, 1821 April 2016. Transportation Research Procedia, 14, 3895-3904.

[39] Lizbetin, J. \& Stopka, O. (2016). Practical application of the methodology for determining the performance of a combined transport terminal. In 3rd International Conference on Traffic and Transport Engineering (ICTTE), 24-25 November 2016 (pp. 382-387). Beograd, Serbia. 